\title{
Soviet Atheism as a Science, a Worldview, and a Social Discipline (Review)
}

Oleg Kyselov

Victoria Smolkin's book A Sacred Space Is Never Empty: A History of Soviet Atheism is based on the study of archive materials and interviews with former scientific atheists. The author studied 16 different archives in Kyiv (Ukraine), Moscow, Saint Petersburg (Russia), and Vilnius (Lithuania). She also conducted 14 interviews, including with some respondents who cannot provide additional information any longer, because they have since passed away. These include Nikolai Gordienko (1929-2011), Evgraf Duluman (1928-2013), and Nikolai Zakovich (1931-2017). Victoria Smolkin undoubtedly also used the available literature on scientific atheism, documents of the Communist Party of the USSR, and other sources in her research.

At the beginning of her book, Smolkin presents the three existing narratives on religion and atheism in the USSR: 1) antireligious repressions; 2) the role of atheism in the project of utopianism and cultural revolution, and 3) Soviet religious policy as a form of secular modernity. These three narratives have appeared chronologically, but all of them regard Soviet communism as a totalitarian political religion (p. 7). This is also the interpretation of the book under review. Unlike her predecessors, however, Smolkin considers atheism to be an important part of the Soviet ideology and talks about atheistic upbringing.

The book accounts for Soviet atheism from 1917 till 1991. Smolkin suggests that during the period of militant atheism (until 1943), religion was considered a political problem, but in the period of scientific atheism (starting in 1954), it was seen as a worldview problem. The global rise of religion in the public space (starting at the end of the 1970s) restored it as a political problem for the Communist party and ideological activists.

The focus of the book is directed at Khrushchev's and Brezhnev's times. Atheism itself is considered in three different forms: as a science, a worldview, and a social discipline. In the first case, the author implies science was an instrument of atheist propaganda. Smolkin illustrates this with the case of using cosmic themes in atheist propaganda. Atheism was part of the scientific and materialist worldview and appealed to human reason. But the author, using her study of primary sources, confirms that the Communist Party and ideological activists recognized this was not sufficient to constitute effective propaganda and that propagandists would also need to appeal to human emotion. That was the way Soviet atheism transformed from a brutal critic of religion towards an optimistic non-religious worldview. The appeal to emotions in 
religious rites provoked the Communist Party to develop new non-religious rites and introduce them to Soviet society. The author found out that even though new rites were an integral part of life in the late Soviet Union, its citizens continued to take part in religious rituals as well. She explains this with a shared ideological indifference, on the one hand, and with an interest in religion as a cultural phenomenon on the other. People participated in church services and sacraments - as the author of the reviewed book discovered - not because of religious motives but because of their aesthetic and entertainment value. People treated going to church, as Smolkin writes, in the same way as going to the theatre or circus.

Soviet atheism, in the author's opinion, was not about secularism or secularization but the conversion of Soviet citizens to atheism. The idea of replacement is stressed throughout the whole book - the sacred space of religion was supposed to be filled with its secular analogue (museums and planetariums instead of temples, cosmonauts instead of saints and prophets, scientific atheists instead of priest and preachers, Soviet rites instead of church rituals). But Smolkin also states that "Soviet atheism was not secular because secularism can tolerate indifference" (p. 241), but "[f] or Soviet atheism, however, the privatization of religion was never acceptable in the long term, and indifference and neutrality were unacceptable positions" (p. 242).

Smolkin compares the situation with religion in the USSR to the fate of the Cathedral of Christ the Saviour in Moscow. The Cathedral was destroyed in 1931, to be replaced with the Palace of the Soviets. Eventually, a swimming pool was built there instead, in 1960. In the same way, atheism attempted to fill the space exempted from religion, but it left an empty space instead. Soviet citizens, liberated from religion, didn't automatically become atheists. As the Soviet sociological surveys demonstrated, a significant part of the Soviet population had become indifferent towards religion and atheism simultaneously.

Unquestionably, the book under review will be interesting not only for scholars focused on atheism and the antireligious policy in the USSR. The book is written in a sufficiently dynamic way, constantly changing its focus from specific examples to a general image of the situation and back. The used archive materials turn the book into unique and fascinating research which reflects the various aspects of Soviet society, culture, and ideology. I am convinced that Smolkin's book will attract the attention of historians, anthropologists, and sociologists, as well as scholars of religion, culture, and politics.

\section{References}

Smolkin, Victoria, A Sacred Space Is Never Empty: A History of Soviet Atheism, Princeton: Princeton University Press 2018, 360 p. 